\title{
Two step procedure for early diagnosis of polycystic kidney disease with polymorphic DNA markers on both sides of the gene
}

\author{
M H Breuning, F G M Snijdewint, J G Dauwerse, J J Saris, E Bakker, P L Pearson, \\ G J B van Ommen
}

\begin{abstract}
Polymorphic DNA markers can now be used for presymptomatic and prenatal diagnosis of the autosomal dominant form of polycystic kidney disease (PKD). A detailed map is known for the chromosomal region around the PKD1 gene on the short arm of chromosome 16. We present here a simple, two step procedure for diagnosis of PKD1 by family studies. Using this approach, at least $92 \%$ of random subjects are informative for polymorphic DNA markers bracketing the PKD1 gene. The recombination rate between these flanking markers is on average $10 \%$. In non-recombinants $(90 \%$ of family members), the accuracy of diagnosis using DNA markers is $>99 \%$. We conclude that sufficient well defined DNA markers are now available for routine diagnosis of PKD1.

We recommend, however, that prenatal diagnosis of PKD by chorionic villi sampling should be attempted only after the linkage phase of the DNA markers has been established by haplotyping the index family. Since autosomal dominant PKD has been found to be genetically heterogeneous, families should be of sufficient size to rule out the rare form of PKD not caused by a mutation on the short arm of chromosome 16 .
\end{abstract}

The adult form of polycystic kidney disease (PKD) is one of the most frequent inherited diseases of man.

Department of Human Genetics, State University Leiden, PO Box 9503, 2300 RA Leiden, The Netherlands.

M H Breuning, F G M Snijdewint, J G Dauwerse, J J Saris, E Bakker, G J B van Ommen

Welch Medical Library, The Johns Hopkins University, Laboratory for Applied Research in Academic Information, 1830 E Monument Street, Baltimore, Maryland 21205, USA.

P L Pearson

Correspondence to Dr Breuning.

Received for publication 2 April 1990. Accepted for publication 8 May 1990.
The slow but relentless growth of cysts in the kidney commonly leads to end stage renal failure at the age of 40 to 60 years. At the time the disease is detected, most patients have already passed on the mutation to their offspring. For genetic counselling, a reliable method for presymptomatic and prenatal diagnosis is needed. As a first step, the mutation responsible for polycystic kidney disease (PKD1) was mapped to the short arm of chromosome $16,{ }^{1}$ closely linked to 3'HVR, a highly polymorphic DNA marker, located $8 \mathrm{~kb}$ downstream from the $3^{\prime}$ end of the haemoglobin $\alpha$ gene cluster. ${ }^{1-3}$ Recently, several families with autosomal dominant PKD have been described where the mutation was not linked to genetic markers on chromosome $16,{ }^{45}$ indicating genetic heterogeneity of PKD. A series of probes for the short arm of chromosome 16 has been developed since. ${ }^{6-8}$ The purpose of this study was to combine the probes isolated by a number of different groups and develop a standard protocol for early diagnosis of PKDl with linked DNA markers.

\section{Materials and methods}

Detailed description of the probes, family studies, and map of chromosome 16 are presented elsewhere. ${ }^{8}$ The RFLPs detected by the various probes used for diagnosis of PKDl are listed in table 1. DNA from peripheral blood was isolated by standard methods. ${ }^{8}$ Ultrasonography was used to detect cysts in asymptomatic family members as described previously. ${ }^{9}$ To correct for false negative diagnosis we used the criteria formulated by Bear et al. ${ }^{10}$

\section{TWO STEP PROCEDURE}

Step 1

DNA from all family members is cut with four restriction enzymes. The blots are hybridised with $3^{\prime}$ HVR as a marker distal to the gene, and four proximal markers, 24-1, 26-6, VK5, and CRI-090. The $3^{\prime}$ HVR probe is heterozygous in more than $90 \%$ of subjects, ${ }^{2}$ and the four proximal probes together are informative in $81 \%$ (see table 1 for PIC values). In 
Table 1 Polymorphic markers on chromosome 16 used in the two step procedure.

\begin{tabular}{|c|c|c|c|c|c|}
\hline Probe & $\begin{array}{c}\text { HGM } \\
\text { number }\end{array}$ & $\begin{array}{c}\text { Restriction } \\
\text { enzyme }\end{array}$ & $\begin{array}{l}\text { Fragment } \\
(\mathbf{k b})\end{array}$ & Frequency & PIC \\
\hline $\begin{array}{l}3^{\prime} \mathrm{HVR} \\
5^{\prime} \mathrm{HVR}\end{array}$ & $D 16 S 85$ & $\begin{array}{l}\text { PvuIII* }_{\text {RsaI* }} \\
\text { R }\end{array}$ & $\begin{array}{l}A-X \\
A-X\end{array}$ & & \\
\hline $\begin{array}{l}\text { S } \\
\text { Fr3-42 }\end{array}$ & $D 16 S 21$ & BamHI & $\begin{array}{ll}A-A & 1 \cdot 2 \\
\text { S1 } & 1 \cdot 2 \\
\text { S2 } & 1 \cdot 1 \\
\text { S3 } & 1 \cdot 0 \\
\text { S4 } & 3 \cdot 0 \\
\text { S5 } & 2 \cdot 8\end{array}$ & $\begin{array}{l}0.33 \\
0.02 \\
0.65 \\
0.84 \\
0.16\end{array}$ & 0.38 \\
\hline 2BP5 & $D 16 S 21$ & $\begin{array}{l}P s t \mathrm{I} \\
X m n \mathrm{I}\end{array}$ & $\begin{array}{ll}\text { S6 } & 1 \cdot 3 \\
\text { S7 } & 1 \cdot 1 \\
\text { S8 } & 7 \cdot 0 \\
\text { S9 } & 3 \cdot 5\end{array}$ & $\begin{array}{l}0.37 \\
0.63 \\
0.28 \\
0.72\end{array}$ & $\begin{array}{l}0.36 \\
0.32\end{array}$ \\
\hline $\begin{array}{l}\text { HMJ1 } \\
\text { pEKMDA }\end{array}$ & $\begin{array}{l}D 16 S 21 \\
D 16 S 83\end{array}$ & $\begin{array}{l}\text { TaqI* } \\
\text { PstI* }\end{array}$ & $\begin{array}{l}\text { (Sa-Sx) } \\
(\mathrm{Ta}-\mathrm{Tx})\end{array}$ & & \\
\hline pGGGI & D16S84 & PstI & $\begin{array}{ll}\text { U3 } & 1 \cdot 9 \\
\text { U4 } & 1 \cdot 5 \\
\text { U5 } & 1 \cdot 2\end{array}$ & $\begin{array}{l}0.15 \\
0.61 \\
0.24\end{array}$ & 0.49 \\
\hline $26-6$ & $D 16 S 125$ & $\operatorname{TaqI^{*}}$ & $\begin{array}{ll}\text { E1 } & 5.8 \\
\text { E2 } & 0.85\end{array}$ & $\begin{array}{l}0.27 \\
0.73\end{array}$ & 0.32 \\
\hline VK 5 & $D 16 S 94$ & MspI & $\begin{array}{ll}\text { V1 } & 1.6 \\
\text { V2 } & 1.3\end{array}$ & $\begin{array}{l}0.57 \\
0.43\end{array}$ & 0.37 \\
\hline 218EP6 & $D 16 S 246$ & PvuII* & $\begin{array}{ll}\mathrm{Ha} & 2.8 \\
\mathrm{Hb} & 2.5\end{array}$ & $\begin{array}{l}0.43 \\
0.36 \\
0.64\end{array}$ & 0.36 \\
\hline $24-1$ & $D 16 S 80$ & TaqI & $\begin{array}{ll}\text { B1 } & 3 \cdot 8 \\
\text { B2 } & 1 \cdot 5 / 1 \cdot 3 \\
\text { B3 } & 1 \cdot 5\end{array}$ & $\begin{array}{l}0.80 \\
0.13 \\
0.07\end{array}$ & 0.31 \\
\hline CRI-090 & $D 16 S 45$ & EcoRI & $\begin{array}{ll}\text { P1 } & 20 \cdot 0 \\
\text { P2 } & 13.0\end{array}$ & $\begin{array}{l}0.56 \\
0.44\end{array}$ & 0.37 \\
\hline 41-1 & $D 16 S 82$ & SacI & $\begin{array}{ll}\text { D1 } & 7.4 \\
\text { D2 } & 4.0\end{array}$ & $\begin{array}{l}0.80 \\
0.20\end{array}$ & 0.27 \\
\hline CRI-133 & D16S58 & HindIII & $\begin{array}{ll}\text { Q1 } & 7.0 \\
\text { Q2 } & 6.4\end{array}$ & $\begin{array}{l}0.31 \\
0.69\end{array}$ & 0.34 \\
\hline
\end{tabular}

HGM = human gene mapping, $\mathrm{PIC}=$ polymorphism information content. ${ }^{*}$ More restriction enzymes are known to show polymorphism. ${ }^{6}$

this way a haplotype of linked markers is constructed for the affected chromosome. In large families, the haplotype can be derived with a high degree of confidence, leading to reliable predictions of PKD1 in a diagnostic situation. However, in practice, small family size often leads to an uncertain linkage phase of the markers, further complicated by double heterozygous matings and recombination. The recombination rate between $3^{\prime} \mathrm{HVR}$ and $24-1$ or CRI-090 is approximately $10 \% .{ }^{8}$ Usually, recombinations can be mapped, or phase problems can be resolved with the second set of markers (see below).

\section{Step 2}

The blots from step 1 are stripped and hybridised with a second set of probes (table 2 ). In addition, new blots can be made with the enzymes SacI, HindIII, BamHI, PstI, RsaI, and XmnI. If $3^{\prime} \mathrm{HVR}$ is not informative in step 1 , a probe for a second hypervariable region near the $\alpha$ globin gene can be used, the $5^{\prime}$ HVR probe. ${ }^{11}$ An apparent recombination between $P K D 1$ and 3'HVR can be characterised further with two probes for highly polymorphic regions closer to $P K D 1, \mathrm{pEKMDA}$ and $\mathrm{HMJ} 1$, or still more proximal with the three allele polymorphism detected by pGGG1. ${ }^{12}$ This probe is preferred to CMM65, ${ }^{13}$
Table 2 Two step procedure for the diagnosis of PKD using linked DNA markers.

\begin{tabular}{|c|c|c|c|}
\hline \multicolumn{2}{|c|}{ Step 1} & \multicolumn{2}{|c|}{ Step 2} \\
\hline Enzyme & Probe & Enzyme & Probe \\
\hline $\begin{array}{l}\text { PvuII } \\
\text { TaqI } \\
\text { MspI }\end{array}$ & $\begin{array}{l}3^{\prime} \text { HVR } \\
24-1+26-6 \\
\text { VK } 5\end{array}$ & & $\begin{array}{l}\text { 218EP6 } \\
\text { pEKMDA }\end{array}$ \\
\hline EcoRI & CRI-090 & $\begin{array}{l}\text { HindIII } \\
\text { SacI } \\
\text { XmmI } \\
\text { BamHI } \\
\text { PstI } \\
\text { RsaI }\end{array}$ & $\begin{array}{l}\text { HMJ 1 } \\
\text { CRI-133 } \\
41-1 \\
\text { 2BP5 } \\
\text { Fr 3-42 } \\
\text { pGGG1 } \\
\text { 5'HVR }\end{array}$ \\
\hline
\end{tabular}

because its small allele is in strong linkage disequilibrium with the $\mathrm{U} 4$ allele detected by pGGG1, while the large allele of CMM65 is subdivided into U3 and U5 of pGGG1 (data not shown). Thus pGGG1 is more informative. In addition, four RFLPs can be used at the $D 16 S 21$ locus, located halfway between $3^{\prime} \mathrm{HVR}$ and $P K D 1 .^{8}$

Uncertainty of the phase or lack of informativeness of proximal markers may be resolved by using the probes 218EP6, 41-1, and CRI-133, which detect RFLPs on the centromeric side of $P K D 1$. If after step 2 the segregation of the markers on the short arm of 
chromosome 16 is still unclear, additional markers could be studied. . $^{-8}$

\section{Discussion}

A substantial proportion of frequently occurring inherited diseases with as yet unknown causes can now be diagnosed by pedigree analysis, by following polymorphic DNA markers linked to the affected gene in a family study. The markers used for routine diagnosis should be thoroughly characterised beforehand. The accuracy of diagnosis is greatly increased when closely linked probes on both sides of the gene are available. In addition, the markers have to be informative in a large number of random subjects. Ideally, hypervariable regions bracketing the gene at very small genetic distance should be available. Four of these hypervariable regions are now available on the distal side of $P K D 1$ (table 1). ${ }^{8}$ Proximal to $P K D 1$, however, only simple restriction site polymorphisms are available. Therefore, to achieve informativeness on both sides of the gene, DNA from family members should be digested with three restriction enzymes, to make blots which can be hybridised with four probes proximal to $P K D 1$. The most rational approach to such laborious and costly family studies is to design a standard procedure for diagnosis and carrier detection, using RFLPs on both sides of a disease gene. This was first designed for Duchenne muscular dystrophy by Bakker et al. ${ }^{14}$ We have adapted this concept here to the diagnosis of polycystic kidney disease.

\section{PITFALLS}

Diagnosis of hereditary disease using linked DNA markers is now performed routinely in many laboratories. Analysis of families with Duchenne muscular dystrophy (DMD), haemophilia A and B, and cystic fibrosis have indicated pitfalls that may lead to inaccurate diagnosis. For example, the DMD gene is very large, ${ }^{15}$ and probes located within the gene can show intragenic recombinations that may lead to erroneous diagnosis. ${ }^{1617}$ Therefore, the use of flanking markers outside the gene is still necessary in those cases where the mutation causing the disease has not been determined. ${ }^{14}$ As the PKDl gene is not known, we have to be careful and base diagnosis on paired flanking markers whenever possible.

A second practical problem is the interpretation of complex banding patterns, sometimes obtained with probes for hypervariable regions. Using less stringent hybridisation conditions, the $3^{\prime} \mathrm{HVR}$ shows many bands, ${ }^{18}$ seriously hampering the recognition of the chromosome 16 specific bands.

Another pitfall concerns the disease entity. Pathologists and nosologists have had long lasting debates on the classification and diagnosis of cystic disease of the kidney. ${ }^{19}$ The many forms of cystic kidney can be subdivided into several large groups, such as inherited cysts, autosomal recessive and autosomal dominant, cysts as part of a malformation syndrome, secondary cysts, and simple isolated cysts. ${ }^{19} \mathrm{~W}$ ith this multitude of heterogeneous types of cysts, problems with the diagnosis of individual patients are only to be expected. Therefore, diagnosis of PKD using markers on chromosome 16 should be applied only in those families where dominantly inherited polycystic kidney disease is well documented through several generations.

The autosomal dominant form of PKD is now known to be genetically heterogeneous. ${ }^{45}$ Although it is difficult to estimate the frequency of 'unlinked' PKD, it must be small, because genetic heterogeneity was not found among 27 families from four countries. ${ }^{20}$ Nevertheless, 'unlinked' families have now been detected by several laboratories, including our own. ${ }^{8}$ In such cases the family study with paired flanking markers on chromosome 16 shows apparent double recombinants. The chances of missing such independent segregation is in fact quite small, given a reasonable family size. For the sake of completeness, we also include non-paternity as an obvious, but not infrequent, source of error in all genetic linkage studies.

\section{PRENATAL DIAGNOSIS}

Prenatal diagnosis of adult polycystic kidney disease has been performed using $3^{\prime} \mathrm{HVR}$ as a single marker, which gave an accuracy of approximately $95 \% .^{21}$ The procedure described above, although more laborious and costly, will give an accuracy of more than $99 \%$ in non-recombinants when paired flanking members are informative. Incorrect predictions will occur only in the very rare cases of double recombination, once between $P K D 1$ and the proximal marker and once more between $P K D 1$ and the distal marker. In cases where a recombination between flanking markers is actually detected, the genotype at the $P K D I$ locus is no longer predictable. The recombination frequency between 3'HVR and 24-1 or CRI-090 is approximately $10 \% .{ }^{8}$ Now that several polymorphic loci are available within this interval, the percentage of such cases will be much less than $10 \%$. Parents requesting prenatal diagnosis for PKD have to be thoroughly informed by careful genetic counselling on this limitation of the diagnostic procedure. The reliability of the diagnosis is strongly enhanced by extensive previous family study. We recommend, therefore, that until more specific studies on the mutation(s) causing PKD are feasible, genetic counselling and family studies should be performed before pregnancy.

The procedure described above is straightforward and effective in many families, but it is laborious, costly, and time consuming. Recently, several efficient 
techniques have been described for the detection of DNA sequence variation. ${ }^{22-30}$ By combining the polymerase chain reaction $(\mathrm{PCR})^{31} 32$ with these techniques, the polymorphisms can be visualised rapidly without using radioactive label. Using denaturing gradient gel electrophoresis (DGGE), ${ }^{22}$ we have detected polymorphisms in the sequence recognised by $26-6 .{ }^{33}$ We are now designing a set of PCRDGGE primers for polymorphic regions flanking the PKDl gene that could be used for rapid, unequivocal identification of haplotypes within families. If this strategy bears fruit, the diagnosis of polycystic kidney disease using linked DNA markers will be much improved.

The search for the PKDl gene is now drawing to a close. Flanking markers are available, and the long range restriction map of the region is almost complete (Germino et al, Harris et al, in preparation). It can be expected, however, that even after the gene responsible for polycystic kidney disease on chromosome 16 has been identified, the use of family studies with flanking markers will remain necessary for some time. First, it will be the best way to identify families with the 'unlinked' form of PKD (PKD2). Secondly, the number of different mutations at $P K D 1$ is not known and may be large. If so, as in DMD, it will not be feasible to detect each mutation directly for diagnostic purposes. We predict, therefore, that the approach described here, and similar, more refined ones as further markers become available, will be the standard method for presymptomatic and prenatal diagnosis of polycystic kidney disease for at least some years to come.

The studies were financed by the Netherlands Kidney Foundation.

1 Reeders ST, Breuning MH, Davies KE, et al. A highly polymorphic DNA marker linked to adult polycystic kidney disease on chromosome 16. Nature 1985;317:542-4

2 Jarman AP, Nicholls RD, Weatherall DJ, Clegg JB, Higgs DR. Molecular characterisation of a hypervariable region downstream of the alpha-globin gene cluster. $E M B O \mathcal{F} 1986 ; 5$ : 1857-63.

3 Reeders ST, Breuning MH, Corney G, et al. Two genetic markers closely linked to adult polycystic kidney disease on chromosome 16. Br Med F 1986;292:851-3.

4 Romeo G, Devoto M, Costa G, et al. A second genetic locus for autosomal dominant polycystic kidney disease. Lancet 1988;ii: 8-10.

5 Kimberling WJ, Fain PR, Kenyon JB, Goldgar D, Sujansky E, Gabow PA. Linkage heterogeneity of autosomal polycystic kidney disease. $N$ Engl f Med 1988;319:913-7.

6 Kidd KK, Bowcock AM, Schmidtke J, et al. Report of the DNA committee and catalogs of cloned and mapped genes and DNA polymorphisms. Cytogenet Cell Genet 1989;51:622-947.

7 Reeders ST, Hildebrand CE. Report of the committee on the genetic constitution of chromosome 16. Cytogenet Cell Genet 1989;51:299-318.

8 Breuning MH, Snijdewint FGM, Brunner H, et al. Map of 16 polymorphic loci on the short arm of chromosome 16 close to the polycystic kidney disease gene (PKD1). F Med Genet 1990;27:603-13.

9 Hogewind BL, Veltkamp JJ, Koch CW, de Graeff J. Genetic counseling for adult polycystic kidney disease. Ultrasound a useful tool in presymptomatic diagnosis? Clin Genet 1980;18: 168-72.

10 Bear JC, McManamon P, Morgan J, et al. Age at clinical onset and at ultrasonographic detection of adult polycystic kidney disease-data for genetic counseling. Am $\mathcal{F}$ Med Genet 1984;18: 45-53.

11 Jarman AP, Higgs DR. A new hypervariable marker for the human alpha globin gene cluster. Am F Hum Genet 1988;43: 249-56.

12 Germino GG, Barton NJ, Lamb J, et al. Identification of a locus which shows no recombination with autosomal dominant polycystic kidney disease gene on chromosome 16. Am $\mathcal{F ~ H u m}$ Genet 1990;46:925-33.

13 Nakamura Y, Martin C, Krapcho K, et al. Isolation and mapping of a polymorphic DNA sequence (pCMM65) on chromosome 16 (D16S84). Nucleic Acids Res 1988;16:3122.

14 Bakker E, Bonten EJ, de Lange LF, et al. DNA probe analysis for carrier detection and prenatal diagnosis of Duchenne muscular dystrophy: a standard diagnostic procedure. $\mathcal{F}$ Med Genet 1986;23:573-80.

15 Den Dunnen JT, Grootscholten PM, Bakker E, et al. Topography of the Duchenne muscular dystrophy (DMD) gene: FIGE and cDNA analysis of 194 cases reveals 115 deletions and 13 duplications. Am F Hum Genet 1989;45:835-47.

16 Darras BT, Harper JF, Francke U. Prenatal diagnosis and detection of carriers with DNA probes in Duchenne's muscular dystrophy. N Engl f Med 1987;316:985-92.

17 Grimm T, Müller B, Dreier M, et al. Hot spot of recombination within DXS164 in the Duchenne muscular dystrophy gene. Am f Hum Genet 1989;45:368-72.

18 Fowler SJ, Gill P, Werrett DJ, Higgs DR. Individual specific DNA fingerprints from a hypervariable region probe: alphaglobin 3'HVR. Hum Genet 1988;79:142-6.

19 Zerres K, Volpel MC, Weiss H. Cystic kidneys: genetics, pathologic anatomy, clinical picture and prenatal diagnosis. Hum Genet 1984;68:104-35.

20 Reeders ST, Breuning MH, Ryynanen MA, et al. A study of genetic linkage heterogeneity in adult polycystic kidney disease. Hum Genet 1987;76:348-51.

21 Reeders ST, Zerres K, Gal A, et al. Prenatal diagnosis of autosomal dominant polycystic kidney disease using a DNA probe. Lancet 1986;ii:7-9.

22 Myers RM, Maniatis T, Lerman LS. Detection and localisation of single base changes by denaturing gel electrophoresis. Methods Enzymol 1987;155:501-27.

23 Myers RM, Sheffield VC, Cox DR. Detection of single base changes in DNA: ribonuclease cleavage and denaturing gradient gel electrophoresis. In: Genomic analysis: a practical approach. Oxford: IRL Press, 1988:95-139.

24 Saiki RK, Walsh PS, Levenson CH, Erlich HA. Genetic analysis of amplified DNA with immobilized sequence-specific oligonucleotide probes. Proc Natl Acad Sci USA 1989;86:6230-4.

25 Tautz D. Hypervariability of simple sequences as a general source for polymorphic DNA markers. Nucleic Acids Res 1989;17: 6463-71.

26 Smeets HJM, Brunner HG, Ropers HH, Wieringa B. Use of variable simple sequence motifs as genetic markers: application to study of myotonic dystrophy. Hum Genet 1989;83:245-51.

27 Cotton RGH, Rodriques NR, Campbell RD. Reactivity of cytosine and thymidine in single-base-pair mismatches with hydroxylamine and osmium tetroxide and its application to the study of mutations. Proc Natl Acad Sci USA 1988;85: $4397-401$.

28 Orita $M$, Suzuki Y, Sekiya T, Hayashi K. Rapid and sensitive detection of point mutations and DNA polymorphisms using the polymerase chain reaction. Genomics 1989;5:874-9.

29 Gibbs RA, Nguyen PN, Caskey CT. Detection of single DNA base differences by competitive oligonucleotide priming. Nucleic Acids Res 1989;17:2437-48.

30 Newton CR, Graham A, Heptinstall LE, et al. Analysis of any point mutation in DNA. The amplification refractory mutation system (ARMS). Nucleic Acids Res 1989;17:2503-16.

31 Saiki RK, Gelfand DH, Stoffel S, et al. Primer-directed enzymatic amplification of DNA with a thermostable DNA polymerase. Science 1988;239:487-91.

32 Saiki RK, Gyllensten UB, Erlich HA. The polymerase chain reaction. In: Genomic analysis: a practical approach. Oxford: IRL Press, 1988:141-52.

33 Saris JJ, Breuning MH, Dauwerse HG, et al. Rapid detection of polymorphism near gene for adult polycystic kidney disease. Lancet 1990;i:1102-3. 